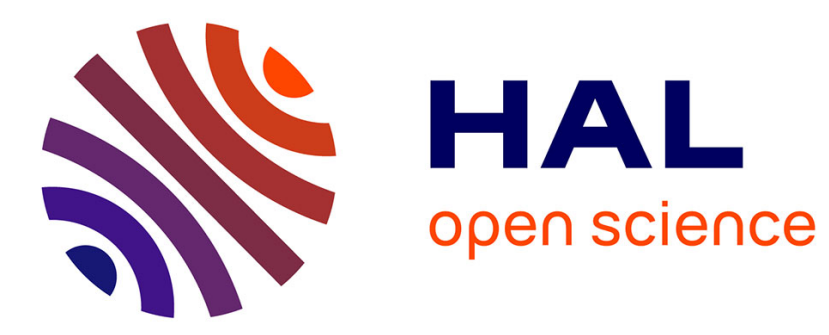

\title{
A scientific note on trail pheromone communication in a stingless bee, Scaptotrigona pectoralis (Hymenoptera, Apidae, Meliponini)
}

\author{
Stefan Jarau, Kathrin Hemmeter, Ingrid Aguilar, Manfred Ayasse
}

\section{- To cite this version:}

Stefan Jarau, Kathrin Hemmeter, Ingrid Aguilar, Manfred Ayasse. A scientific note on trail pheromone communication in a stingless bee, Scaptotrigona pectoralis (Hymenoptera, Apidae, Meliponini). Apidologie, 2011, 42 (6), pp.708-710. 10.1007/s13592-011-0070-4 . hal-01003607

\section{HAL Id: hal-01003607 https://hal.science/hal-01003607}

Submitted on 1 Jan 2011

HAL is a multi-disciplinary open access archive for the deposit and dissemination of scientific research documents, whether they are published or not. The documents may come from teaching and research institutions in France or abroad, or from public or private research centers.
L'archive ouverte pluridisciplinaire HAL, est destinée au dépôt et à la diffusion de documents scientifiques de niveau recherche, publiés ou non, émanant des établissements d'enseignement et de recherche français ou étrangers, des laboratoires publics ou privés. 


\title{
A scientific note on trail pheromone communication in a stingless bee, Scaptotrigona pectoralis (Hymenoptera, Apidae, Meliponini)
}

\author{
Stefan JARAU ${ }^{1}$, Kathrin Hemmeter ${ }^{1}$, Ingrid Aguilar ${ }^{2}$, Manfred Ayasse ${ }^{1}$ \\ ${ }^{1}$ Institute for Experimental Ecology, University of Ulm, Albert-Einstein-Allee 11, 89081 Ulm, Germany \\ ${ }^{2}$ Center for Tropical Bee Research (CINAT), National University of Costa Rica, P.O. Box 475-3000, Heredia, Costa Rica
}

Received 23 July 2010 - Revised 17 February 2011 - Accepted 21 February 2011

stingless bee / recruitment communication / trail pheromone / labial glands / nest specificity

Foragers of eusocial stingless bees use a variety of communication mechanisms to inform their nestmates about the presence of valuable food sources and to recruit workers to the task of food collection (e.g., Barth et al. 2008). Recruitment to food sources at specific locations is particularly effective in species that use pheromones deposited by foragers at the resource and at various spots on the substrate along their flight root back towards the nest (Lindauer and Kerr 1960). Among these species are bees of the genus Scaptotrigona, which are said to produce the respective marking pheromones in their mandibular glands (Lindauer and Kerr 1960). However, an experimental proof for this assumption was never provided and recent experiments have shown that labial gland secretions of Scaptotrigona pectoralis foragers release trail following behaviour in recruited workers (Reichle et al. 2011). In addition, experiments testing the effect of natural gland extracts on recruited workers of three Trigona species (Jarau et al. 2006, 2010; Schorkopf et al. 2007) and of Geotrigona mombuca (Stangler et al. 2009) have unequivocally demonstrated that their trail pheromones are exclusively secreted from the foragers' labial glands. Therefore, it is reasonable to assume that mandibular gland secretions of Scaptotrigona workers are not involved in trail pheromone communication, as stated in earlier works. We tested this assumption in bioassays using artificial scent trails

Corresponding author: S. Jarau, stefan.jarau@uni-ulm.de

Manuscript editor: Bernd Grünewald baited with gland secretions, extracted in organic solvent, in bioassays carried out with a colony of $S$. pectoralis in Heredia, Costa Rica between July and November 2007 (gland extraction procedure, concentration of gland extracts and experimental set-up as described by Jarau et al. 2006). We trained foragers to sugar water feeders and allowed them to recruit additional workers in their nest. We then observed whether the recruited bees were attracted to scent trails that branched off from the bees' natural trails when we baited them with (a) mandibular gland extract, (b) labial gland extract or (c) the pure solvent hexane (control experiments). Each recruit was captured and colour marked for identification in later experiments. For the analyses, we only used unmarked bees, which were naive in respect to both experimental set-up and foraging site. Neither hexane-baited trails nor trails made with mandibular gland extracts released trail following behaviour in the recruits (Figure 1). By contrast, compared to the hexane control trails, a significantly larger proportion of the bees followed trails baited with labial gland extracts and reached the test feeders at their end rather than the recruitment feeders, at which the recruiting foragers collected sugar solution (Figure 1). Thus, as in Trigona and Geotrigona species, the trail pheromone of $S$. pectoralis is exclusively secreted from the foragers' labial glands and compounds from the bees' mandibular glands play no role in scent trail communication in this species. Our experiments also showed that trails baited with the pheromone extracted from nestmate foragers were more attractive to the recruits than trails baited with the pheromone from conspecific workers collected from a different 
colony (Figure 1; foreign labial glands vs. parental labial glands). A similar observation was recently reported for Trigona corvina (Jarau et al. 2010). However, in this aggressively foraging species, in which encounters between workers from different colonies at food sources lead to fierce fights ending in the death of the involved individuals (Biesmeijer and Slaa 2004), foreign trail pheromones were completely avoided. In our experiments with $S$. pectoralis, a foreign trail pheromone still attracted recruited bees, although it was less attractive than their nestmates' pheromone. S. pectoralis foragers from different colonies do not fight with each other when they meet at food sources (Biesmeijer and Slaa 2004). Following the scent trail of non-nestmate foragers and reaching a food source exploited by foreign workers, therefore, is not as disastrous in this species as it would be in T. corvina. We, therefore, conclude that the use of nest-specific information in trail pheromone communication in stingless bees is strongly influenced by a species' aggressiveness and foraging ecology.

Note scientifique: Communication par une phéromone de marquage de piste chez une abeille sans aiguillon, Scaptotrigona pectoralis (Hymenoptera, Apidae, Meliponini)

Eine wissenschaftliche Notiz über die Kommunikation mittels Spurpheromonen bei der stachellosen Biene Scaptotrigona pectoralis (Hymenoptera, Apidae, Meliponini)

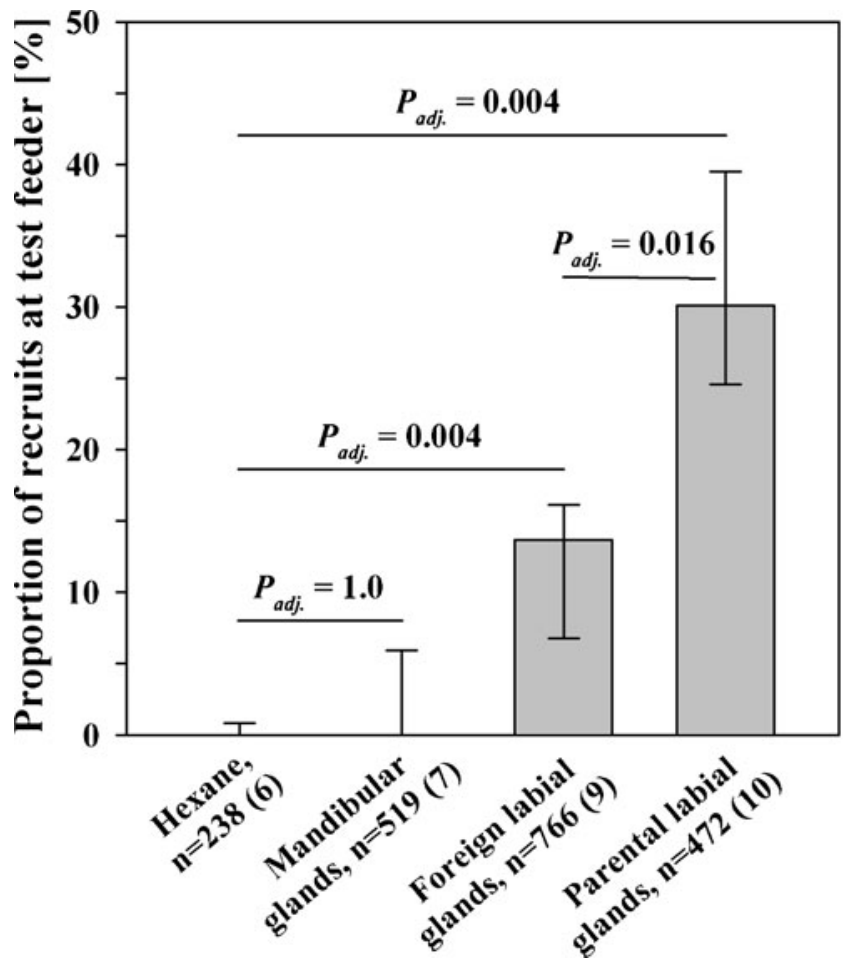

Figure 1. Percentage of $S$. pectoralis recruits that followed artificial scent trails baited with different test substances $(x$-axis; $100 \%=$ sum of recruits at the feeder at the end of the test trail and at the feeder to which their nestmates were recruited). Extracts of parental labial glands were prepared from nestmates of the tested bees. Extracts of foreign labial glands were prepared from the foragers of another $S$. pectoralis colony. Boxes include the median, whiskers give the 25th and 75th percentiles. Significance levels were calculated with MannWhitney tests and adjusted according to the Bonferroni method. Total numbers of individual bees tested $(n)$ and number of conducted experiments (in brackets) are given for each test substance. 


\section{REFERENCES}

Barth, F.G., Hrncir, M., Jarau, S. (2008) Signals and cues in the recruitment behavior of stingless bees (Meliponini). J. Comp. Physiol. A 194, 313-327

Biesmeijer, J.C., Slaa, E.J. (2004) Information flow and organization of stingless bee foraging. Apidologie 35, 143-157

Jarau, S., Schulz, C.M., Hrncir, M., Francke, W., Zucchi, R., Barth, F.G., Ayasse, M. (2006) Hexyl Decanoate, the first trail pheromone compound identified in a stingless bee, Trigona recursa. J. Chem. Ecol. 32, 1555-1564

Jarau, S., Dambacher, J., Twele, R., Aguilar, I., Francke, W., Ayasse, M. (2010) The trail pheromone of a stingless bee, Trigona corvina (Hymenoptera, Apidae, Meliponini), varies between populations. Chem. Sens. 35, 593-601
Lindauer, M., Kerr, W.E. (1960) Communication between the workers of stingless bees. Bee World 41, 29-41 and $65-71$

Reichle C, Aguilar I, Ayasse M, Jarau S (2011) Stingless bees (Scaptotrigona pectoralis) learn foreign trail pheromones and use them to find food, J Comp Physiol A 197, 234249

Schorkopf, D.L.P., Jarau, S., Francke, W., Twele, R., Zucchi, R., Hrncir, M., Schmidt, V.M., Ayasse, M., Barth, F.G. (2007) Spitting out information: Trigona bees deposit saliva to signal resource locations. Proc. R. Soc. B. 274, 895-898

Stangler, E.S., Jarau, S., Hrncir, M., Zucchi, R., Ayasse, M. (2009) Identification of trail pheromone compounds from the labial glands of the stingless bee Geotrigona mombuca. Chemoecology 19, 13-19 